\title{
IMPLEMENTASI MATA KULIAH AKUNTANSI MANAJEMEN SEBAGAI MEDIA PEMBELAJARAN KESEHARIAN MAHASISWA FKIP AKUNTANSI UNIVERSITAS PGRI PALEMBANG
}

\author{
Oleh :Hendri Gunawan \\ (UNIVERSITAS PGRI PALEMBANG)
}

jayasampurna85@gmail.com

\begin{abstract}
Abstrak
Penelitian ini dilakukan di Program Studi Pendidikan akuntansi Universitas PGRI Palembang. Berdasarkan pengamatan peneliti, banyak dari mahasiswa FKIP akuntansi yang merupakan mahasiswa kos (mengontrak) dimana mereka selalu memiliki jumlah uang yang selalu diterimanya untuk perbulannya. Seringkali penggunaan uang mahasiswa tersebut direncanakan dan digunakan hanya berdasarkan kebutuhan yang bersifat sesaat atau mendesak. Maka penelitian ini ingin melakukan pembuktian apakah setelah diajarkan matakuliah Akuntansi Manajemen mahasiswa mampu merencanakan dan mengalokasikan keuangan yang mereka peroleh dengan baik dan benar. Dari hasil sebaran kuesioner kepada 30 mahasiswa FKIP Akuntansi semester VI dengan 14 aitem pertanyaan dapat diketahui $>80 \%$ responden telah memahami matakuliah akuntansi manajemen dan telah menerapkan perencanaan dan pengalokasian keuangan yang merekamiliki dengan baik pada setiap bulannya.
\end{abstract}

Kata Kunci: Akuntansi Manajemen, Mahasiswa Kos, Program Studi pendidikan Akuntansi Universitas PGRI PAlembang

\section{IMPLEMENTATION OF MANAGEMENT ACCOUNTING COURSES AS A MEDIUM OF DAILY LEARNING FKIP STUDENTS ACCOUNTING PGRI UNIVERSITY OF PALEMBANG}

\begin{abstract}
This research was conducted in the study program of Education Accounting at PGRI University, Palembang. Researchers found many accounting students live in a renting house. They receive their living costs from their parents monthly. They often use those money unplanned. This research has aim to prove whether teaching accounting management course to those students, could affect the way they spent their monthly living costs correctly. Researchers asked 14 questions to a 30 accounting students at 4th Semester. The results show that after taking the course, $>80 \%$ of students had applied a good planning and allocating for their monthly budget.
\end{abstract}

Keywords: Accounting management, renting a house, students of Education Accounting of PGRI University-Palembang. 


\section{PENDAHULUAN}

Tujuan pembelajaran akuntansi bagi mahasiswa FKIP Akuntansi Univ. PGRI Palembang adalah mencetak lulusan berupa tenaga pendidik yang profesional dan mampu bersaing di dunia kerja sebagai seorang tenaga pendidik bidang studi akuntansi. Mahasiswa FKIP Akuntansi Univ. PGRI Palembang berasal dari berbagai daerah baik yang berasal dari Kota Palembang maupun yang berasal dari luar daerah Kota Palembang. Hasil pengamatan observasi sementara peneliti dari jumlah seluruh mahasiswa Program Studi FKIP Akuntansi dengan jumlah mahasiswa kurang lebih 670 mahasiswa hampir 75\% mahasiswa FKIP Akuntansi Univ. PGRI Palembang adalah mahasiswa kos dengan kata lain tidak berdomisilih di Kota Palembang. Menurut Panen (2001:18) menjelaskan bahwa dalam teori belajar bermakna (Meaningful teaching theory) mengemukanakan bahwa kebermaknaan penyajian dan pentingnya pengetahuan kemajuan belajar (advance organizer) dimana bahwa belajar harus dirancang dengan baik agar menarik bagi peserta didik. Oleh karena itu belajar yang efektif dapat dikatakan sebagai proses belajar yang menggabungkan pengetahuan dan seluruh alat indra sehingga mendapat hasil yang optimal. Contohnya; ketika siswa akan belajar tentang bidang studi ekonomi, maka cara belajar yang efektif adalah dengan cara melihat atau mengamati pelajarannya secra langsung. Mulut membaca (mengulang bacaannya), telinga mendengar, dan tangan menulis rangkuman dengan katakata sendiri atau mengerjakan latihan pelajaran yang sedang dipelajari. Sehingga pelajaran tersebut tidak mudah lupa dan pelajaran itu juga dapat mudah dipahami dengan baik. Bukan dengan cara menghapal pelajaran yang pada akhirnya akan cepat lupa. Karena ciri khas dari hasil belajar/kemampuan yang diperoleh adalah jika seseorang dapat merumusakan kembali pengetahuan yang dimiliki dengan katakata sendiri. Menurut Magnesen dalam Slameto (2010:15) pada kenyataannya kita belajar $10 \%$ dari apa yang kita baca, 20\% dari apa yang kita dengar, $70 \%$ dari apa yang kita katakan, dan 90\% dari apa yang kita katakan dan lakukan.

Jika teori yang telah dipaparkan diatas maka dalam kehidupan seharihari mahasiswa kos pada dasarnya memiliki dana keuangan yang relatif 
tidak stabil hal ini disebabkan oleh uang yang mereka terima dari orang tua terbatas pada kebutuhan primer sedangkan seringkali uang tersebut tidak mencakup kebutuhan sekunder mahasiswa diluar uang kulaih dan biaya kos mahasiswa seperti : biaya foto copy makalah, biaya buku, biaya liburan, dan biaya lain-lain yang takterduga.

Matakuliah akuntansi manajemen di FKIP Akuntansi Universitas PGRI Palembang diajarkan kepada mahasiswa pada semester VI Mata kuliah ini membahas materi pemahaman akan klasifikasi biaya, penggunaan biayabiaya, analisis laba dari penggunaan biaya, analisis diferensial dari alternatifalternatif penggunaan biaya yang ada, dan efektifitas penggunaan modal kerja sesuai dengan kebutuhan pihak yang bersangkutan serta mekanisme perhitungan pencatatan keuangan. Pada mata kuliah ini mahasiswa dituntut untuk mengetahui jenis-jenis biaya dan alokasinya agar memiliki manfaat yang lebih, serta prosedur sitematika pencatatan pembiayaan keuangan tersebut.

Selanjutnya untuk mengetahui keterkaitan mata kuliah akuntansi manajemen tersebut pada kehidupan sehari-hari mahasiswa FKIP Akuntansi
Univ. PGRI Palembang, akan diketahui dengan menyebarkan kuesioner kepada mahasiswa yaitu mahasiswa FKIP Akuntansi Semester VI tahun akademik 2013/2014 yang telah mengikuti mata kuliah akuntansi manajemen yang merupakan mahasiswa kos yang nantinya akan dievaluasi, dianalisis serta direvisi/dikembangkan untuk mendapatkan hasil yang maksimal. Adapun materi perkuliahan yang dijadikan aitem pertanyaan pada kuesioner yaitu :

1. Perilaku Biaya

2. Analisis Laba Biaya dan Volume

3. Analisis Diferensial Biaya

4. Activity Based Costing (ABC)

5. Variable Costing

Dari hasil kuesioner tersebut akan di tabulasikan untuk mengetahui persentase keterkaitan atau pengaruhnya. Dari materi perkuliahan Akuntansi Manajemen peneliti merasakan adanya keterkaitan antara kehidupan keseharian mahasiswa kos dengan materi kuliah akuntansi manajemen dalam hal memaksimalkan penggunaan biaya hidup sehari-hari mereka. 


\section{KAJIAN TEORI}

\section{Hakikat Hasil Belajar}

Setiap proses belajar mengajar selalu mengharapkan menghasilkan hasil belajar, baik berupa perubahan individu yang belajar akan memperoleh hasil dari apa yang telah dipelajari selama proses belajar itu. H. Menurut Dajamarah (2004: 45), hasil belajar adalah prestasi dari suatu kegiatan yang telah dikerjakan, diciptakan, baik secara individual maupun kelompok. Hasil belajar tidak akan pernah ada selama orang tidak melakukan sesuatau. Untuk menghasilkan sebuah prestasi dibutuhkan perjuangan dan pengorbanan yang sangat besar. Hanya dengan keuletan, sungguh-sungguh, kemauan yang tinggi dan rasa optimisme dirilah yang mampu untuk menciptakannya, sementara itu Arikunto (2007:115) mengatakan bahwa hasil belajar adalah hasil akhir setelah mengalami proses belajar, perubahan itu tampak dalam perbuatan yang dapat diamati, dan dapat diukur.

Purwanto (2010:3) menyatakan bahwa hasil belajar adalah suatu yang digunakan untuk menilai hasil pelajaran yang telah diberikan kepada siswa dalam waktu tertentu. Berdasarkan berbagai pendapat diatas dapat disimpulkan bahwa hasil belajar yaitu suatu perubahan yang terjadi pada individu yang belajar, bukan hanya perubahan mengenai pengetahuan, tetapi juga untuk membentuk kecakapan, kebiasaan, pengertian, penguasaan, dan penghargaan dalam diri seseorang yang belajar.

\section{Karakteristik Pembelajaran} Akuntansi Manajemen

Akuntansi memiliki fungsi untuk mengembangkan pengetahuan, keterampilan, sikap rasional, teliti, jujur, dan bertanggung jawab melalui prosedur pencatatan, penggolongan, pengikhtisaran transaksi keuangan, penyusunan laporan keuangan dan penafsiran perusahaan berdasarkan Standar Akuntansi Keuangan (SAK).

Dalam pelaksanan kurikulum pendidikan pada tingkat Universitas khususnya Fakultas Keguruan dan Ilmu Pendidikan (FKIP) pembelajaran Akuntansi mengutamakan :

a. Menyiapkan dunia mahasiswa untuk memasuki lapangan kerja serta mengembangkan sikap profesional.

b. Menyiapkan mahasiswa mamapu menjadi tenaga 
pendidik akuntansi yang profesional, maupun mengembangkan karir dibidang akuntansi untuk mencapai kehidupan yang lebih baik.

c. Menyiapkan tenaga kerja pada tingkat strata 1 untuk mengisi kebutuhan dunia kerja dan industri saat ini dan yang akan datang.

Diperjelas pada ketetapan MPR Nomor IV/1999 bidang pendidikan Nomor 22 tahun 2000 yaitu "Prospek dan tantangan di masa depan merupakan integrasi dari globalisasi ekonomi, sebagai bagian ilmu ekonomi yang mempelajari siklus/proses kegiatan dari seluruh transaksi keuangan perlu dilaksanakan di tingkat pendidikan untuk membangun perpektif pemahaman dan keterampilan akuntansi". Mata kuliah Akuntansi Manajemen di FKIP Akuntansi Univ. PGRI Palembang di ajarkan pada semester VI. Adapun materi pokok perkuliahan mata kuliah Akuntansi Manajemen di tingkat Universitas khususnya FKIP Pendidikan Akuntansi adalah sebagai berikut:

1. Klasifikasi konsep dan Terminologi Biaya
2. Perilaku Biaya

3. Analisis Laba Biaya dan Volume

4. Analisis Diferensial Biaya

5. Activity Based Costing (ABC)

6. Variable Costing

7. Penentuan Harga Jual

Proses pembelajaran akuntansi manajemen ini lebih ditekankan dalam rangka memenuhi perkembangan perspektif manajemen sebagai input perencanaan, pengendalian, serta pengambilan keputusan dari sekian banyak alternatif yang dihadapi terutama dalam mencapai tujuan maksimalisasi kesejahteraan manajer dan kesehatan organisasi perusahaan. Akuntansi manajemen pun memerlukan pengetahuan untuk menangani masalah keuangan dan operasional bisnis diantaranya pengelolaan sumberdayaa keuangan baik bersifat pembiayaan operasional maupun invertasi modal kerja perusahaan.

Mata kuliah akuntansi manajemen ini merupakan satu kesatuan dari pembelajaran akuntansi yang utuh sehingga keterampilan dan kemampuan yang diharapkan saling berkaitan satu dengan yang lainnya dengan mengutamakan pencapaian melalaui pelatihan yang dialami langsung oleh 
mahasiswa melalaui proses pencatatan, pengelompokan, pengikhtisaran dan pelaporan keuangan suatu proses akuntansi. Dari penjelasan tersebut penulis berkeinginan untuk mengetahui keterkaitan matakuliah akuntansi manajemen dalam implementasinya pada kehidupan sehari-hari mahasiswa program studi pendidikan akuntansi universitas PGRI Palembang. Dalam penelitian ini diharapkan pada mahasiswa khususnya agar nantinya adanya peningkatan pemahaman dan implikasi dari mata kuliah tersebut sehingga tidak hanya sebatas pengetahuan saja.

\section{Implementasi Pembelajaran}

\section{Akuntansi Manajemen}

Implementasi adalah bermuara pada aktivitas, aksi, tindakan, atau adanya mekanisme suatu sistem. Implementasi bukan sekedar aktivitas, tetapi suatu kegiatan yang terancana dan untuk mencapai tujuan kegiatan (Usman, 2002:70). Pengertian implementasi yang dikemukankan dapat dikatakan bahwa implementasi adalah bukan sekedar aktivitas, tetapi suatu kegiatan yang terencana dan dilakukan secara sungguh-sungguh berdasarkan acuan norma tertentu untuk mencapai tujuan kegiatan. Oleh karena itu implementasi tidak berdiri sendiri tetapi dipengaruhi oleh objek berikutnya.

Mata kuliah akuntansi manajemen adalah mata kuliah pokok baik di program studi manajemen ataupun akuntansi. Pada mata kuliah akuntansi manajemen mencakup pembahasan materi kuliah yang membahas terminologi biaya, analisis penggunaan biaya, penggunaan biaya secara efektif, dan penerapan pembiayaan pada kegiatan yang akan dilaksanakan.

Implementasi perkuliahan akuntansi manajemen oleh mahasiswa tercermin dari fungsi pembelajaran akuntansi manajemen itu sendiri yaitu untuk mengembangkan pengetahuan, keterampilan, sikap rasional dalam pengelolaan keuangan, yang teliti, jujur, dan bertanggung jawab melalui prosedur yang sesuai dengan kebutuhan berdasarkan Standar Akuntansi Keuangan (SAK). Pada mata kuliah akuntansi manajemen ini juga memberikan pemahaman kepada mahasiswa tentang pengelolaan keuangan yang terdiri dari biaya-biaya dan investasi modal agar efektif dan evisien dalam penggunaannya. Pada penelitian implementasi yang dimaksud 
yaitu penerapan pembelajaran mata kuliah akuntansi manajemen dalam pengelolaan keuangan dalam kehidupan sehari-hari mahasiswa, Khususnya mahasiswa FKIP Akuntansi Universitas PGRI Palembang semester IV tahun akademik 2013/2014.

\section{METODE PENELITIAN}

Penelitian ini adalah penelitian populasi adalah mahasiswa FKIP akuntansi Univ. PGRI Palembang semester VI yang telah mengikuti mata kuliah akuntansi manajemen yang saya ajar, banyaknya populasi adalah 30 mahasiswa

Teknik analisis data yang digunakan dalam penelitian ini adalah teknik analisis deskriptif kualitatif. Teknik analisis secara kualitatif digunakan menganalisis hasil sebaran kuesioner yang telah diberikan kepada 30 responden yang merupakan mahasiswa semester VI FKIP Akuntansi angkatan 2013/2014. Analisis deskriptif kualitatif diterapkan pada kuesioner yang telah diuji faliditas datanya dan telah disebar kepada responden.

Instrumen yang digunakan dalam penelitian ini bersifat nonmekanis melalui surve penelitian dengan instrument utama berupa kuesioner. Pengujian kuesioner dengan tiga cara yaitu : uji validitas, uji reliabilitas. Untuk menguji instrumen keusiner yang kan digunakan peneliti menggunakan olahan data validitas dan reliabilitas dengan SPSS. 24.

\section{HASIL PENELITIAN DAN PEMBAHASAN}

Peneltian ini merupakan penelitian deskriptif dengan satu variabel utama yaitu implemetasi matakuliah akuntansi manajemen sebagai media pembelajaran keseharian mahasiswa. Sistematika penelitian ini diteapkan kepada mahasiswa yang telah mengikuti matakuliah akuntansi manajemen dan dilakukan penelitian. Hasil penelitian ini diperoleh dari pengolahan data kuesioner yang telah disebar kepada 30 responden/mahasiswa, adapun hasil yang dapat dijabarkan sebagai berikut :

\section{Deskripsi Data Angket Hasil Olahan Data Validitas Dan Reliabilitas Dengan SPSS.24}




\begin{tabular}{|l|r|r|r|r|}
\hline \multicolumn{7}{|c|}{ Tabel 1. Output SPSS Korelasi Butir dengan Total Butir } \\
Item-Total Statistics
\end{tabular}

Menurut Sufren dan Yonathan Natanael (2014:62), untuk menguji validitas suatu data, lihat angka pada kolom Corrected Item-Total Correlation. Butirbutir pertanyaan dinyatakan valid bila nilai korelasinya di atas atau sama dengan 0,2. Jika melihat dari tabel 2 di atas pada kolom Corrected Item-Total Correlation, ada 15 butir item yang valid, sisanya (5) tidak valid.

\section{Tabel 2. Output SPSS Koefisien}

\section{Reliabilitas Alat Ukur}

\begin{tabular}{|c|c|}
\hline \multicolumn{2}{|c|}{ Reliability Statistics } \\
\hline Cronbach's Alpha & N of Items \\
\hline .785 & 19 \\
\hline
\end{tabular}

Tabel 2, menunjukkan nilai reliabilitas. Nilai reliabilitas dilihat dari koefisien Cronbach's Alpha. Cronbach's alpha yang umumnya digunakan sebagai persyaratan sebuah alat ukur berkisar dari 0,6 sampai dengan 0,8 (Sufren dan Yonathan Natanael, 2014:62). Dalam tabel 3 di atas nilai cronbach's alpha sebesar 0,784, sehingga data tersebut reliable. 


\section{Deskripsi Data Hasil Kuesioner}

Tabel 3. Hasil Sebaran Kuesioner

\begin{tabular}{|c|c|c|c|c|c|}
\hline \multirow{2}{*}{ NO. } & \multirow{2}{*}{ Aitem Pertanyaan } & \multicolumn{4}{|c|}{ Skala Pengukuran (\%) } \\
\hline & & 1 & 2 & 3 & 4 \\
\hline 1 & $\begin{array}{l}\text { Membuat rencana keuangan selama satu } \\
\text { bulan }\end{array}$ & 13,33 & 53,33 & 26,67 & 6,67 \\
\hline 2 & $\begin{array}{l}\text { Membuat rencana keuangan dengan pos } \\
\text { berinvestasi di setiap bulan }\end{array}$ & 26,67 & 56,67 & 13,33 & 3,33 \\
\hline 3 & $\begin{array}{l}\text { Saya selalu merencanakan pembiayaan } \\
\text { yang saya butuhkan untuk kebutuhan } \\
\text { saya pada bulan berikutnya }\end{array}$ & 0,00 & 23,33 & 56,67 & 20,00 \\
\hline 4 & $\begin{array}{l}\text { Saya membuat pos pengeluaran rutin } \\
\text { dan kewajiban finansial selama satu } \\
\text { bulan }\end{array}$ & 13,33 & 43,33 & 20,00 & 23,33 \\
\hline 5 & $\begin{array}{l}\text { Dalam menentukan pemakaian uang } \\
\text { saya slalu mempertimbangkan manfaat } \\
\text { yang akan saya peroleh }\end{array}$ & 0,00 & 23,33 & 30,00 & 46,67 \\
\hline 6 & $\begin{array}{l}\text { Saya selalu mengatur seluruh uang yang } \\
\text { saya miliki kedalam berbagai pos } \\
\text { kebutuhan yang terpisah }\end{array}$ & 10,00 & 53,33 & 26,67 & 10,00 \\
\hline 7 & $\begin{array}{l}\text { Saya berusaha untuk tidak menggunakan } \\
\text { uang yang telah saya tetapkan untuk } \\
\text { disimpan }\end{array}$ & 3,33 & 43,33 & 36,67 & 16,67 \\
\hline 8 & $\begin{array}{l}\text { saya mengurangi pos-pos yang telah } \\
\text { direncanakan sebelumnya untuk } \\
\text { memenuhi kebutuhan yang bersifat } \\
\text { mendesak }\end{array}$ & 23,33 & 63,33 & 3,33 & 10,00 \\
\hline 9 & $\begin{array}{l}\text { Saya dapat mengatur pengeluaran uang } \\
\text { yang saya miliki }\end{array}$ & 3,33 & 56.67 & 16,67 & 20,00 \\
\hline 10 & $\begin{array}{l}\text { Saya selalu mengupayakan penggunaan } \\
\text { uang untuk keperluan yang penting }\end{array}$ & 3,33 & 13,33 & 50,00 & 33,33 \\
\hline 11 & $\begin{array}{l}\text { Saya mempertimbangkan antara } \\
\text { kebutuhan pokok dengan kebutuhan } \\
\text { pelengkap dalam kehidupan sehari-hari }\end{array}$ & 3,33 & 26,67 & 30,00 & 40,00 \\
\hline 12 & $\begin{array}{l}\text { Saya selalu mempertimbangkan } \\
\text { pengunaan uang yang saya punya agar } \\
\text { nantinya memiliki kelebihan bukan } \\
\text { kekurangan dalam penggunaanya untuk } \\
\text { setiap bulannya }\end{array}$ & 6,67 & 20,00 & 50,00 & 23,33 \\
\hline 13 & $\begin{array}{l}\text { Mengalokasikan pendapatan minimal } \\
10 \% \text { untuk menabung setiap bulan }\end{array}$ & 23,33 & 60,00 & 3,33 & 13,33 \\
\hline 14 & $\begin{array}{l}\text { Sisa penggunaan uang setiap bulannya } \\
\text { saya tabung }\end{array}$ & 6,67 & 40,00 & 36,67 & 16,67 \\
\hline
\end{tabular}

Berdasarkan hasil kuesioner yang mengikuti mata kuliah Akuntansi disebar kepada 30 responden yaitu Manajemen dapat dilihat pada tabel 3 mahasiswa semester VI yang telah dan Disimpulkan bahwa $>80 \%$ 
responden telah memamhami dan telah menerapkan perencanaan dan pengalokasian keuangan yang merekamiliki dengan baik pada setiap bulannya hal ini dibuktikan dari banyaknya responden yang memilik skala pengukuran 2,3 , dan 4 .

\section{Deskripsi}

implementasi

matkuliah akuntansi manajemen sebagai media pembelajaran dalam kehidupan sehari-hari mahasiswa.

Adapun materi pokok perkuliahan mata kuliah akuntansi manajemen yang dijadikan bahan kajian penelitian yaitu:
1. Perilaku Biaya

2. Analisis Laba Biaya dan Volume

3. Analisis Diferensial Biaya

4. Activity Based Costing (ABC)

5. Variabel Costing

Dari hasil penelitian yang dapat dilihat pada sebaran kuesioner kepada 30 responden dengan 14 aitem pertanyaan dapat disimpulkan sebagai berikut :

1. Materi perkuliahan prilaku biaya pada aitem pertanyaan kuesioner nomer 3, 5, 9, dan14

Gambar 1. Prilaku Biaya
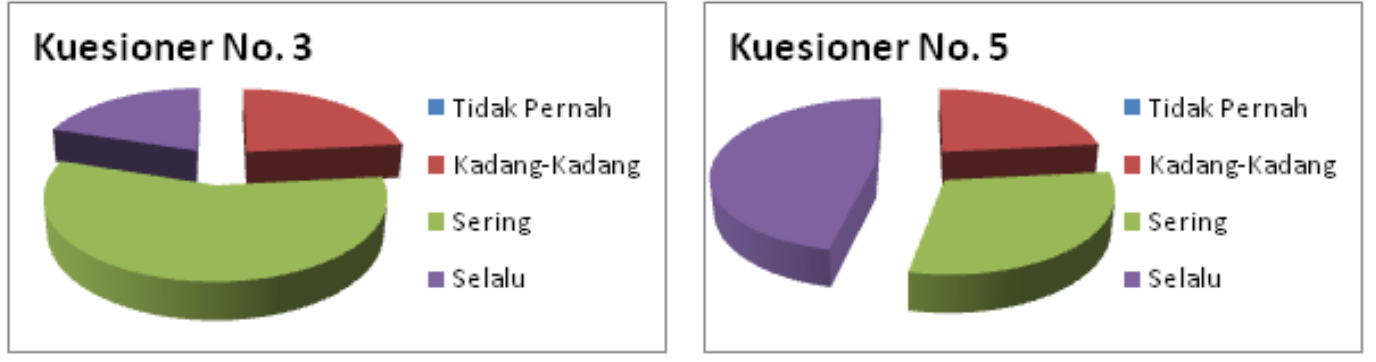

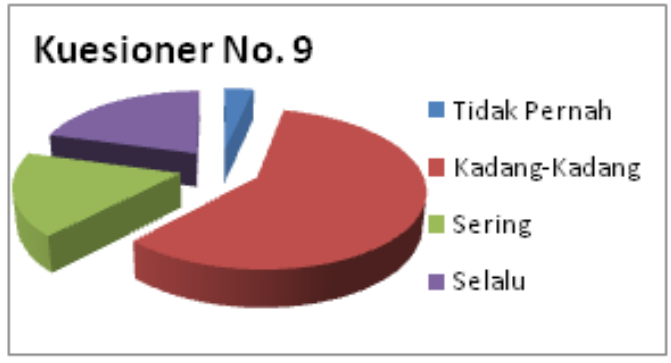

Dilihat dari tabel diatas dapat disimpulkan bahwa rata-rata responden telah memahami dan

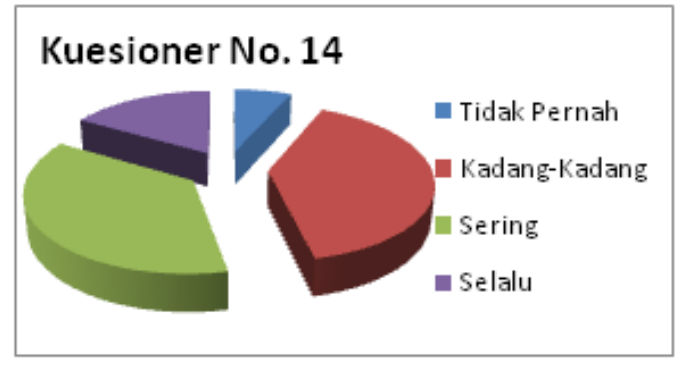

menerapkan prilaku biaya pada perencanaan keuangan mahasiswa tiap bulannya. 
2. Materi perkuliahan analisis laba pertanyaan kuesioner nomer $\mathbf{1}$ dan biaya dan volume pada aitem 13

\section{Gambar 2. Analisis Laba Biaya dan Volume}

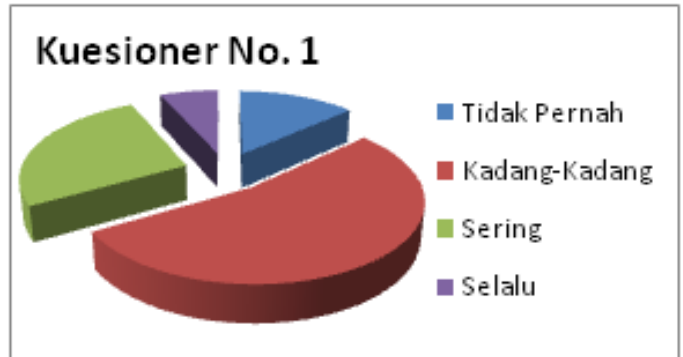

Dilihat dari tabel diatas dapat disimpulkan bahwa $>70 \%$ responden tidak begitu melakukan analisis/menerapkan laba, biaya dan volume baik dalam perencanaan

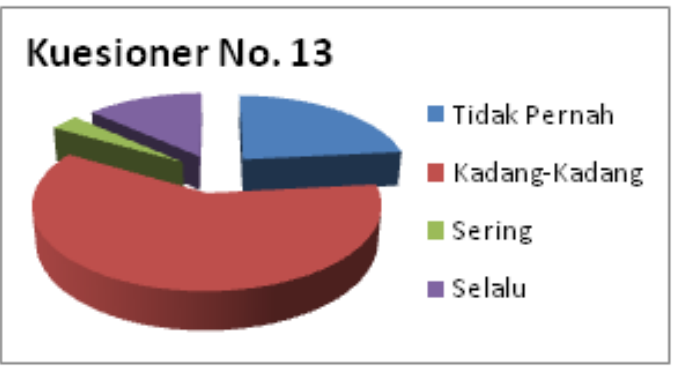

maupun penggunaan keuanga mereka tiap bulannya.

3. Materi perkuliahan analisis diferensial biaya pada aitem pertanyaan kuesioner nomer $\mathbf{8 ,} 11$ dan 12

Gambar 3. Analisis Diferensial Biaya
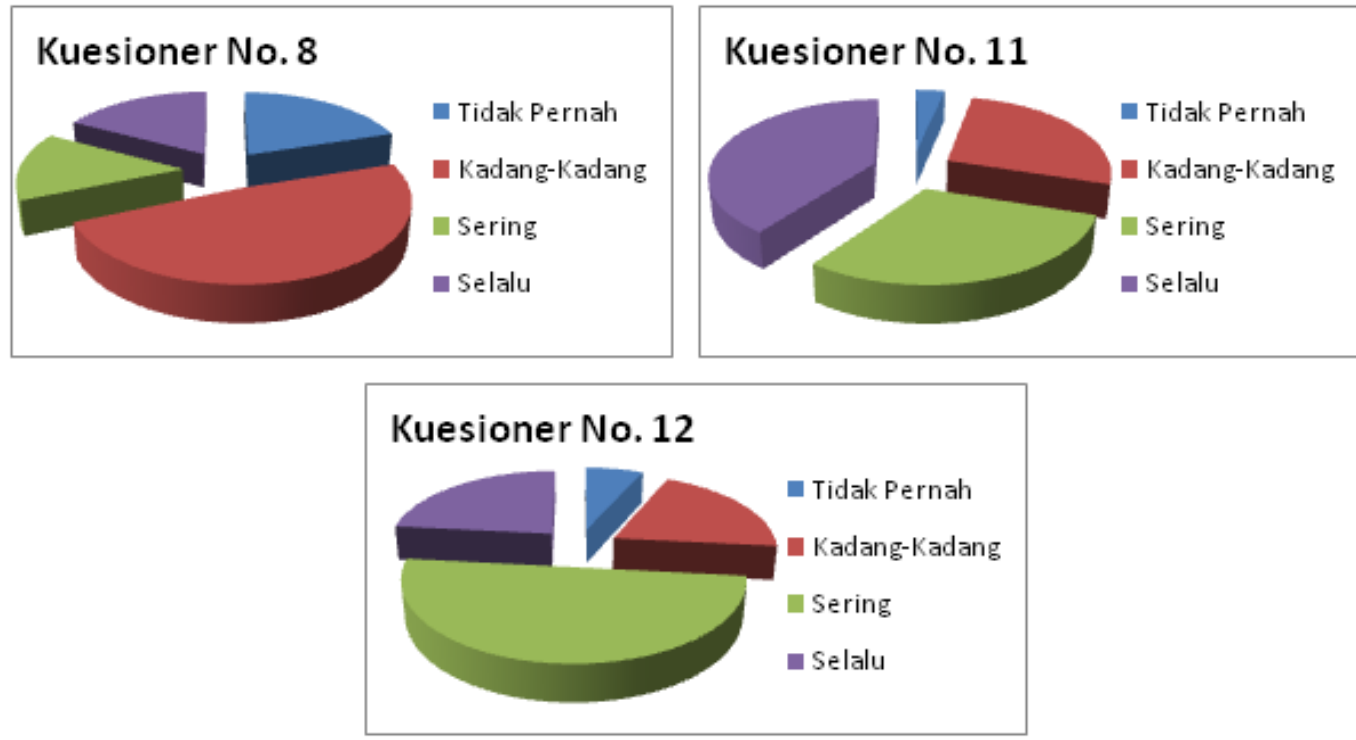

Dilihat dari tabel diatas dapat biaya pada perencanaan maupun disimpulkan bahwa $>70 \%$ penggunaan keuanga mereka tiap responden memahami dan telah bulannya.

menerapkan analisis diferensial 
4. Materi perkuliahan activity based costing pada aitem pertanyaan kuesioner nomer 2, 7 dan 10

Gambar 4. Activity Based Costing
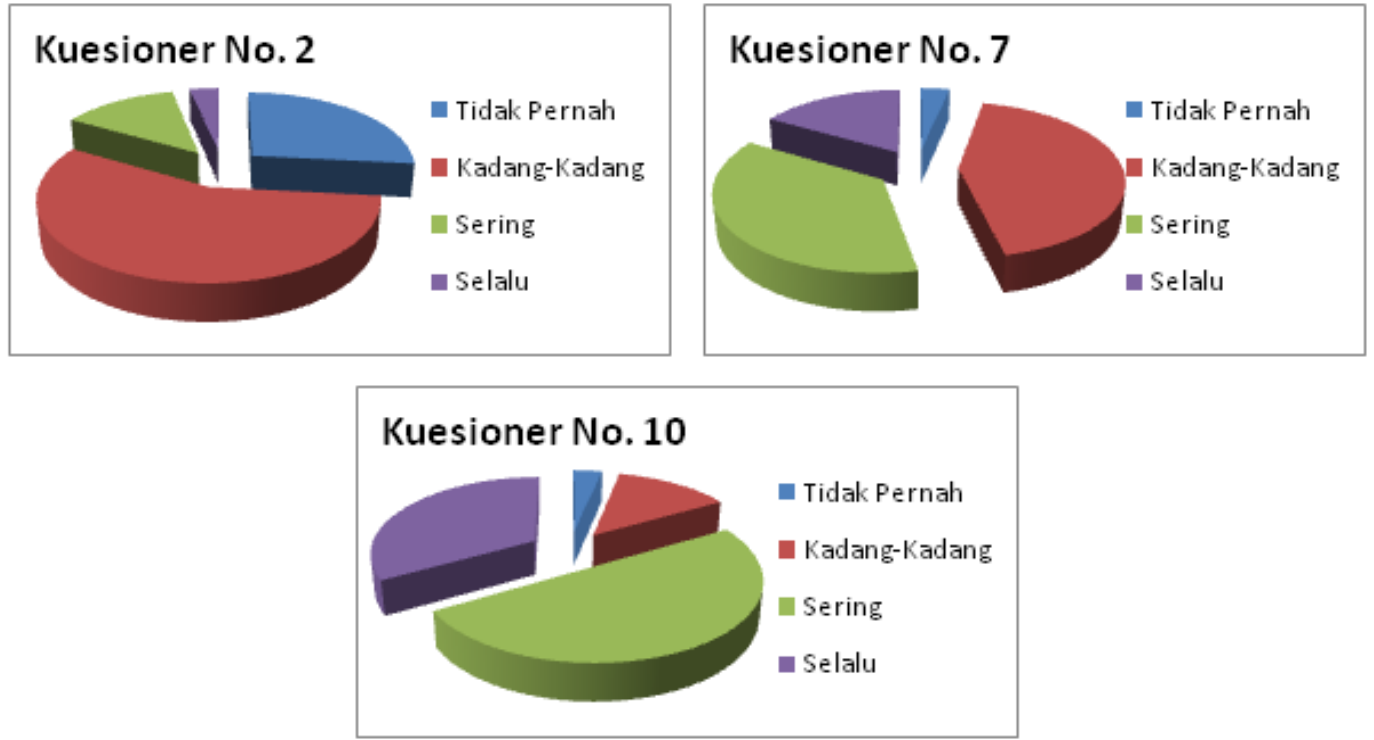

Dilihat dari tabel diatas dapat bulannya, $50 \%$ lainya belum disimpulkan bahwa $50 \%$ menerapkannya.

responden memahami dan telah menerapkan activity based costing pada perencanaan maupun penggunaan keuanga mereka tiap

5. Materi perkuliahan variabel costing pada aitem pertanyaan kuesioner nomer 4 dan 6

\section{Gambar 5. Variabel Costing}

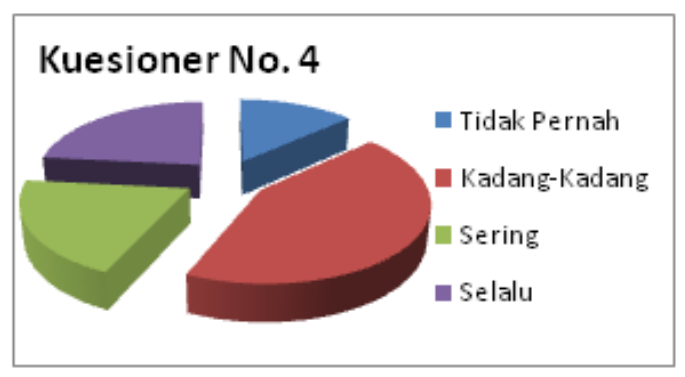

Dilihat dari tabel diatas dapat disimpulkan bahwa $>70 \%$ responden belum memahami dan

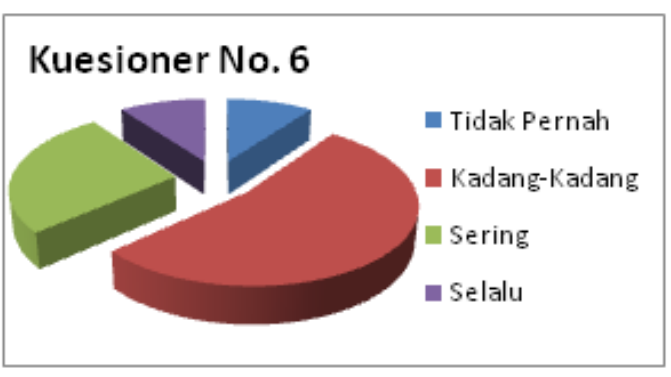

belum menerapkan variabel costing pada perencanaan maupun 
penggunaan keuanga mereka tiap bulannya.

Berdasarkan hasil pengolahan data, ada pengaruh implementasi mata kuliah akuntansi manajemen sebagai media pembelajaran dalam kehidupan sehari-hari mahasiswa semester VI program studi pendidikan akuntansi Univ. PGRI Palembang, peneliti menyimpulkan bahwa implementasi matakuliah akuntansi manajemen memiliki pengaruh yang positif dalam hal memanajemen dan mengalokasikan keuangan yang mereka miliki untuk tiap bulannya khususnya pada mahasiswa semester 6 Prodi. Pendidikan Akuntansi Univ. PGRI Palembang Tahun Pelajaran 2013/2014. Hal ini ditunjukkan dari hasil penyebaran kuesioner kepada 30 responden mahasiswa kos.

\section{SIMPULAN DAN SARAN}

\section{Simpulan}

Dari hasil analisis data penelitian, dapat disimpulkan bahwa:

1. Mahasiswa FKIP Akuntansi sebagian besar belum menerapkan perencanaan yang baik pada keuangan yang mereka miliki tiap bulannya, hal ini dibuktikan pada sebaran kuesioner no. 1, 2, 3, dan 4 dimana persentase mahasiswa memilih skala ukur kuesioner 2, 3, dan 4 cendrung lebih besar dibanding skala ukur 1 .

2. Dalam pengalokasian dana yang dimiliki mahasiswa FKIP Akuntansi cendrung lebih mempertimbangkan hal-hal yang penting dan mengabaikan perencanaan dana yang mereka buat di awalperencanaan, hal ini dibuktikan pada sebaran kuesioner no. 5, 6, 7, $8,9,10,11,12,13$ dan 14 dimana persentase mahasiswa memilih skala ukur kuesioner 2, 3 dan 4 cendrung lebih besar dibanding yang memilih skala ukur 1.

3. Dari hasil sebaran kuesioner secara keseluruhan disimpulkan bahwa mahasiswa semester VI FKIP Akuntansi telah memahami dan menerapakan materi ajar akuntansi manajemen pada perencanaan dan pengalokasian uang yang mereka miliki pada setiap bulannya.

\section{Saran \\ Berkenaan dengan penelitian implementasi mata kuliah akuntansi manajemen sebagai media pembelajaran dalam kehidupan sehari-}


hari mahasiswa Program Studi

Pendidikan Akuntansi Univ. PGRI

Palembang, peneliti mengemukakan

beberapa saran sebagai berikut:

1. Penggunaan media pembelajaran yang berbasis pada materi ajar pada setiap matakuliah hendaknya memperhatikan karakteristik mahasiswa dan dunia kerja agar nantinya dapat diimplementasikan oleh mahasiswa tersebut.

2. Dosen sebagai tenaga pengajar hendaknya dapat mengembangkan media/model/model pembelajaran yang terbarukan, hal ini dimaksudkan agar perkuliahan lebih memotivasi mahasiswa untuk aktiv, kreatif dan inovativ.

\section{DAFTAR PUSTAKA}

Arikunto, S. (2007). Dasar-Dasar Evaluasi Pendidikan. Jakarta: Bumi Aksara.

Djaali dan Muljono. 2010. Pengukuran Dalam Bidang Pendidikan. Jakarta: Grasindo.

Slameto. (2010). Belajar dan FaktorFaktor yang Mempengaruhinya. Jakarta: Rineka Cipta.
Sufren dan Yonathan Natanael. 2014. Belajar Otodidak SPSS Pasti Bisa. Jakarta:PT. Alex Media Komputindo.

Sugiyono.2004. Metode penelitian Pembelajaran. Bandung: Alfabetha.

Suharsimi Arikunto. 2010. Prosedur Penelitian Pendekatan Praktek. Jakarta: suatu.Rineka Cipta.

Istighfarinda. 2014. Implementasi mata kuliah akhlak tasawuf pada perilaku mahasiswa STAIN salatiga angkatan 2010 program Studi PAI tahun 2014.

Agustriyanto, dkk. 2015. Implementasi Pembelajaran Mata Kuliah Kewirausahaan di Fakultas Teknik Universitas Surabaya (UBAYA).

Aristina, dkk. 2014. Implementasi Media Pembelajaran Berbasis Auido Visual pada Matakuliah Sejarah Indonesia Abd 16-19. Jurnal Studi Sosial, Vol 2, No. 4. Jurnal.fkip.unila.ac.id/index.php/J SS/article/view/8110.

Isroah dan Widayati. 2006. Implementasi Pembelajaran Berbasis Kompetensi matakuliah Akuntansi Biaya pada Mahasiswa Jurusan PDU FIS Universitas Negeri Yogyakarta. Jurnal Pendidikan Akuntansi Indonesia, Vol. 5 No.1. Jurnal.uny.ac.id/index.php/jpakun lartikel/view/869. 